\title{
PENGARUH INDEPENDENSI, PENGALAMAN, KOMPETENSI, GAYA KEPEMIMPINAN, DAN BEBAN KERJA AUDITOR TERHADAP SKEPTISME PROFESIONAL AUDITOR
}

\author{
Muh Fardho Asharis Basuki*, Kunti Sunaryo', Indra Kusumawardhani1 \\ 1 Universitas Pembangunan Nasional Veteran Yogyakarta \\ *Email corresponding: asharisfardho1@gmail.com
}

\begin{abstract}
Abstrak
Penelitian ini bertujuan untuk menguji pengaruh independensi, pengalaman, kompetensi, gaya kepemimpinan, dan beban kerja auditor terhadap skeptisme professional auditor pada Auditor di Kantor Akuntan Publik yang berada di Yogyakarta. Sampel pada penelitian ini adalah auditor yang sudah bekerja minimal 1 tahun. Metode pengambilan sampel dalam penelitian ini yaitu dengan metode convenience sampling. Jumlah sampel yang digunakan adalah 39 responden yang merupakan Auditor di Kantor Akuntan Publik di Wilayah Yogyakarta. Teknik analisis data yang digunakan adalah Regresi Linier Berganda. Hasil penelitian ini menunjukkan bahwa independensi auditor berpengaruh terhadap skeptisme professional auditor. Pengalaman auditor berpengaruh terhadap skeptisme professional auditor. Kompetensi auditor berpengaruh terhadap skeptisme professional auditor. Gaya kepemimpinan berpengaruh terhadap skeptisme professional auditor. Sedangkan beban kerja tidak berpengaruh terhadap skeptisme professional auditor.
\end{abstract}

Kata kunci: independensi, pengalaman, kompetensi, gaya kepemimpinan, beban kerja, skeptisme professional

\begin{abstract}
Abstrack
This study aims to examine the effect of independence, experience, competence, leadership style, and workload of auditors on the auditor's professional skepticism on the Auditor at the Public Accountant Office in Yogyakarta. The sample in this study were auditors who had worked for at least 1 year. The sampling method in this study is the convenience sampling method. The number of samples used was 39 respondents who were Auditors at the Public Accountant Office in the Yogyakarta Region. The data were analyzed using double linear regression. The results of this study indicate that auditor independence influences professional auditor skepticism. The auditor's experience influences the auditor's professional skepticism. Auditor competence influences professional auditor skepticism. Leadership style influences auditor professional skepticism. While the workload does not affect the auditor's professional skepticism.
\end{abstract}

Keywords: independence, experience, competence, leadership style, workload

\section{PENDAHULUAN}

Sikap skeptisme seorang auditor adalah sikap yang menandakan profesionalnya sebagai seorang auditor dan harus dimiliki dan diterapkan dalam melakukan setiap tugasnya, salain dari aturan atau ketetapan yang berlaku. SEC (Securities and Exchange Commission) melakukan penelitian melakukan penelitian mengenai hal ini dan memperoleh data bahwa rendahnya sikap skeptisme seorang auditor menjadi salah satu penyebab gagalnya sebuah pelaksanaan audit. Sebanyak 40 kasus yang dijadikan bahan oleh SEC dalam melakukan penelitiannya, dan diperoleh hasil sebanyak 60\% dari kasus terjadinya kegagalan audit disebabkan karena kurangnya sikap skeptisme professional para auditor (Pratami \& Budiarta, 2019).

Kasus yang terjadi pada tahun 2019 Kementerian Keuangan memaparkan tiga kelalaian Akuntan Publik (AP) dalam mengaudit laporan keuangan PT Garuda Indonesia (Persero) Tbk tahun 2018. Hal itu akhirnya berujung sanksi dari Pusat Pembinaan Profesi Keuangan (PPPK). Adapun laporan keuangan tersebut diaudit oleh AP Kasner Sirumapea dari Kantor Akuntan Publik (KAP) Tanubrata, Sutanto, Fahmi, Bambang, dan Rekan. Sekertaris Jendral Kemenkeu Hidayanto menerima ketiga kelalaian yang dilakukan. Pertama, AP bersangkutan belum secara tepat menilai substansi transaksi untuk kegiatan perlakuan akuntansi pengakuan 
pendapatan piutang dan pendapatan lain-lain. Sebab, AP ini sudah mengakui pendapatan piutang meski secara nominal belum diterima oleh perusahaan. Kedua, akuntan publik belum sepenuhnya mendapatkan bukti yang cukup untuk menilai perlakuan akuntansi sesuai dengan substansi pernjanjian transaksi tersebut. Terakhir, AP juga tidak bias mempertimbangkan faktafakta setelah tanggal laporan keuangan sebagai dasar laporan keuangan sebagai dasar perlakuan akuntansi. Ini berarti AP tersebut mengindikasikan bahwa tidak menerapkan sikap skeptisme professionalnya dalam melakukan audit laporan keuangan milik PT Garuda Indonesia.

Skeptisme profesional sangat penting dalam menyelesaikan tugas-tugasnya ada beberapa faktor yang mempengaruhinya, salah satunya independensi. independensi adalah sudut pandang yang tidak bias dalam melakukan ujian audit, mengevaluasi hasilnya dan membuat laporan audit. Auditor tidak hanya harus independen dalam fakta, tetapi juga harus independen dalam penampilan (Seputra, 2013).

Pengalaman auditor juga merupakan salah satu faktor seorang auditor auditor untuk memiliki sikap skeptisme. Suraida (2005) menyatakan bahwa akuntan pemeriksa yang berpengalaman akan memperlihatkan tingkat perhatian selektif yang lebih tinggi terhadap informasi yang relevan. Auditor yang berpengalaman juga akan membuat judgment yang relatif lebih baik dalam tugas-tugasnya.

Faktor lain yang menjadikan auditor dapat memiliki sifat skeptisme profesional adalah kompetensi auditor. Standar umum pertama (SA seksi 210) menyebutkan bahwa audit harus dilaksanakan oleh seorang atau yang memiliki keahlian dan pelatihan teknis yang cukup sebagai auditor.

Faktor lain yang dapat mempengaruhi sifat skeptisme auditor yaitu gaya kepemimpinan dan beban kerja. Gaya kepemimpinan (leadership style) diartikan sebagai hal yang dilakukan pemimpin untuk memberikan pengaruh pada bawahannya sehingga orang yang diberikan pengaruh tersebut mau melakukan perintah pemimpin demi mencapai tujuan organisasi (Pratami \& Budiartha, 2019). Beban kerja adalah jumlah pekerjaan yang harus dilakukan oleh seseorang. Beban kerja auditor dapat dilihat dari banyaknya jumlah klien yang harus ditangani oleh seorang auditor atau terbatasnya waktu auditor untuk melakukan proses audit (Ranu, 2017).

Tujuan dari penelitian ini adalah untuk mencari tahu apa saja faktor-faktor yang menyebabkan auditor untuk bersikap skeptisme professional dalam melaksanakan tugastugasnya sebagai seorang auditor. Peneliti tertarik untuk menjadikan independensi, pengalaman, kompetensi, gaya kepemimpinan, dan beban kerja sebagai variabel independent dikarenakan penelitian sebelumnya yang kurang konsisten. Penelitian tersebut adalah penelitian yang dilakukan oleh (Pratami et al., 2019),(Komala et al., 2019), (Dharmadiaksa et al., 2017), (Hadi \& Hardiyadi, 2014), (Komala et al., 2019), (Novita, 2015).

\section{TINJAUAN PUSTAKA DAN PERUMUSAN HIPOTESIS Skeptisme Profesional}

Skeptisisme adalah sikap yang mencakup pikiran mempertanyakan dan melakukan evaluasi secara kritis. Skeptisisme terjadi ketika ada keraguan mengenai keandalan informasi yang diterima. Ketika seorang individu memiliki keraguan mengenai keandalan informasi yang diberikanoleh klien, ia akan mencari lebih banyak indikasi. Dalam hal ini, seorang auditor yang menunjukkanskeptisisme profesional tingkat tinggi akan mencari lebih banyak informasi dan membuat tambahanmemeriksa untuk merumuskan dasar yang cukup untuk penilaian audit lebih lanjut (Pratami et al., 2019). 
Skeptisme professional auditor diperlukan terutama untuk menjaga citra profesi akuntan publik. Oleh karena itu, dalam hal pengumpulan dan penilaian bukti audit secara objektif menuntut auditor untuk mempertimbangkan kompetensi dan kecukupan buktia audit tersebut. Skeptisme bukanlah sikap sinis, tetapi merupakan sikap yang mengharapkan untuk mempertanyakan, meragukan atau tidak setuju dengan penyajian klien. Tetapi hal ini bukan berarti auditor harus menanamkan asumsi bahwa manajemen tidak jujur dan juga menganggap bahwa kejujuran manajemen tidak perlu dipertanyakan lagi. Oleh karena itu, auditor tidak harus puas dengan bukti yang diberikan manajemen. Sebab, skeptisme professional adalah sikap yang mencakup pikiran yang selalu mempertanyakan dan melakukan evaluasi secara kritis terhadap bukti audit (SA seksi 230).

\section{Independesi}

Seorang akuntan publik tidak boleh terpengaruh oleh pihak-pihak yang berkaitan dengan perusahaanatau klien yang sedang dalam proses pemeriksaan yang dilakukan akuntan publik tersebut (Dewi \& Budiartha, 2015). Independensi adalah sudut pandang yang tidak bias dalam melakukan ujian audit, mengevaluasi hasilnya dan membuat laporan audit. Auditor tidak hanya harus independen dalam fakta, tetapi juga harus independen dalam penampilan (Seputra, 2013).

Skeptisme profesional adalah sikap yang harus dimiliki oleh semua auditor. Salah satu faktor yang dapat meningkatkan sikap skeptisme seorang auditor adalah independensi auditor. Dalam SA Seksi 220 mengharuskan auditor bersikap independen, artinya tidak mudah dipengaruhi, karena Auditor tidak dibenarkan memihak kepada kepentingan siapapun, sebab bagaimanapun sempurnanya keahlian teknis yang ia miliki, ia akan kehilangan sikap tidak memihak yang justru sangat penting untuk mempertahankan kebebasan pendapatnya, Oleh karena itu semakin tingginya independensi seorang auditor yang dimiliki maka semakin tinggi juga sikap skeptisme profesional auditor tersebut.

H1: Independensi berpengaruh positif terhadap skeptisme professional auditor.

\section{Pengalaman}

Pengalaman auditor dalam melakukan audit laporan keuangan baik ditunjukkan dari segi lamanya waktu penyelesaian audit maupun banyaknya penugasan yang pernah ditangani, memperlihatkan bahwa seseorang yang lebih banyak pengalaman dalam suatu bidang subtantif (Dharmadiaksa \& Utama, 2017).

Pengalaman audit ditunjukkan dengan jam terbang auditor dalam melakukan prosedur audit terkait dengan pemberian opini atas laporan auditnya. Pengalaman yang dimaksudkan disini adalah Pengalaman auditor dalam melakukan pemeriksaan laporan keuangan baik dari segi lamanya waktu, maupun banyaknya penugasan yang pernah dilakukan (Winantyadi \& Waluyo, 2014). Cara pandang dan cara menanggapi informasi yang diperoleh selama melakukan pemeriksaan antara auditor yang berpengalaman dengan yang kurang berpengalaman akan berbeda, demikian pula dalam memberikan kesimpulan audit terhadap objek yang diterima. Auditor yang berpengalaman banyak diasumsikan lebih dapat mendeteksi kekeliruan atau kecurangan dalam laporan keuangan karena sikap skeptisme profesional yang dimilikinya, dan dapat menjelaskan temuannya dengan akurat, dibandingkan dengan yang kurang berpengalaman.

H2: Pengalaman berpengaruh positif terhadap skeptisme professional auditor.

\section{Kompetensi}

Dalam melakukan audit, seorang auditor harus memiliki mutu personal yang baik, pengetahuan yang memadai, serta keahlian khusus di bidangnya. Kompetensi berkaitan dengan keahlian profesional yang dimiliki oleh auditor sebagai hasil dari pendidikan formal, ujian profesional 
maupun keikutsertaan dalam pelatihan, seminar, simposium.Kompetensi sebagai suatu keahlianyang cukupdansecara eksplisitdapat digunakan untuk melakukan audit secaraobyektif, ukuran keahlianatau kompetensi tidak cukup hanya pengalaman tetapi diperlukan pertimbanganpertimbanganlain dalam pembuatan suatu keputusan yangbaikkarena padadasarnya manusia memiliki sejumlah unsur lain disamping pengalaman yaitu pengetahuan (Ilmiyati \& Suhardjo, 2012).

Dalam Standar Profesi Akuntan Publik SA seksi 230 menyebutkan bahwa penggunaan kemahiran profesional dengan cermat dan seksama menuntut auditor untuk melaksanakan skeptisisme. Skeptisisme adalah sikap yang mencakup pikiran mempertanyakan dan melakukan evaluasi secara kritis. Auditor menggunakan pengetahuan, keterampilan dan kemampuan yang dituntut oleh profesi akuntan publik untuk melaksanakan dengan cermat dan seksama, dengan maksud baik dan integritas, pengumpulan dan penilaian bukti audit secara obyektif. Hal ini menunjukkan bahwa kompetensi seorang auditor dalam menjalankan tugasnya tidak lepas dari sikap skeptisme profesional yang dimiliki seorang auditor tersebut.

H3: Kompetensi berpengaruh positif terhadap skeptisme professional auditor.

\section{Gaya Kepemimpinan}

Gaya kepemimpinan (leadership style) diartikan sebagai hal yang dilakukan pemimpin untuk memberikan pengaruh pada bawahannya sehingga orang yang diberikan pengaruh tersebut mau melakukan perintah pemimpin demi mencapai tujuan organisasi. Cara pemimpin mempengaruhi bawahannya sangat mempengaruhi kinerja organisasi, sebab untuk meningkatkan kinerja dibutuhkan bimbingan dan arahan dari seorang pemimpin. Untuk itulah pemimpin membawa peranan penting dalam pencapaian tujuan organisasi. Di Indonesia sendiri gaya kepemimpinan menjadi sebuah isu menarik dan membawa dampak besar dalam kehidupan bangsa dan negara (Wijaya, 2015).

Kepemimpinan yang baik dan diterima semua anggota dapat meningkatkan motivasi auditor untuk melaksanakan kewajibannya dengan baik dan tepat waktu (Pratami \& Budiartha, 2019). Pemimpin dalam KAP juga dapat mengarahkan auditor untuk selalu berpegang pada sikap skeptisme profesional dalam menyelesaikan tugas audit yang diterimanya, sehingga meminimalisir adanya kesalahan dan kecurangan. Hal ini berarti menunjukkan bahwa gaya kepemimpinan berpengaruh terhadap sikap skeptisme profesional bawahannya.

H4: Gaya kepemimpinan berpengaruh positif terhadap skeptisme professional auditor.

\section{Beban Kerja}

Beban kerja adalah jumlah pekerjaan yang harus dilakukan oleh seseorang. Beban kerja auditor dapat dilihat dari banyaknya jumlah klien yang harus ditangani oleh seorang auditor atau terbatasnya waktu auditor untuk melakukan proses audit (Ranu, 2017).

Tingginya beban kerja (workload) seorang auditor, yang mana auditor memiliki banyak tugas yang harus diselesaikan sedangkan waktu yang dimiliki terbatas sehingga variasi dalam pencarian informasipun akan beragam. Auditor jadi lebih banyak menyakan dan mencari-cari bukti audit yang dirasa janggal untuk ditanyakan lebih dalam. Hal ini menunjukkan bahwa beban kerja berpengaruh terhadap skeptisme professional aduitor.

H5: Beban kerja berpengaruh positif terhadap skeptisme professional.

\section{Kerangka konseptual}

Kerangka konseptual pada penelitian ini terdiri dari variable independen dan variable dependen, dimana independensi auditor, penglaman auditor, kompetensi auditor, gaya kepemimpinan auditor, dan beban kerja auditor sebagai variabel independent dan skeptisme professional auditor sebagai variabel dependen. Kerangka konseptual dapat dilihat gambar 1 sebagai berikut: 
Gambar 1. Kerangka konseptual
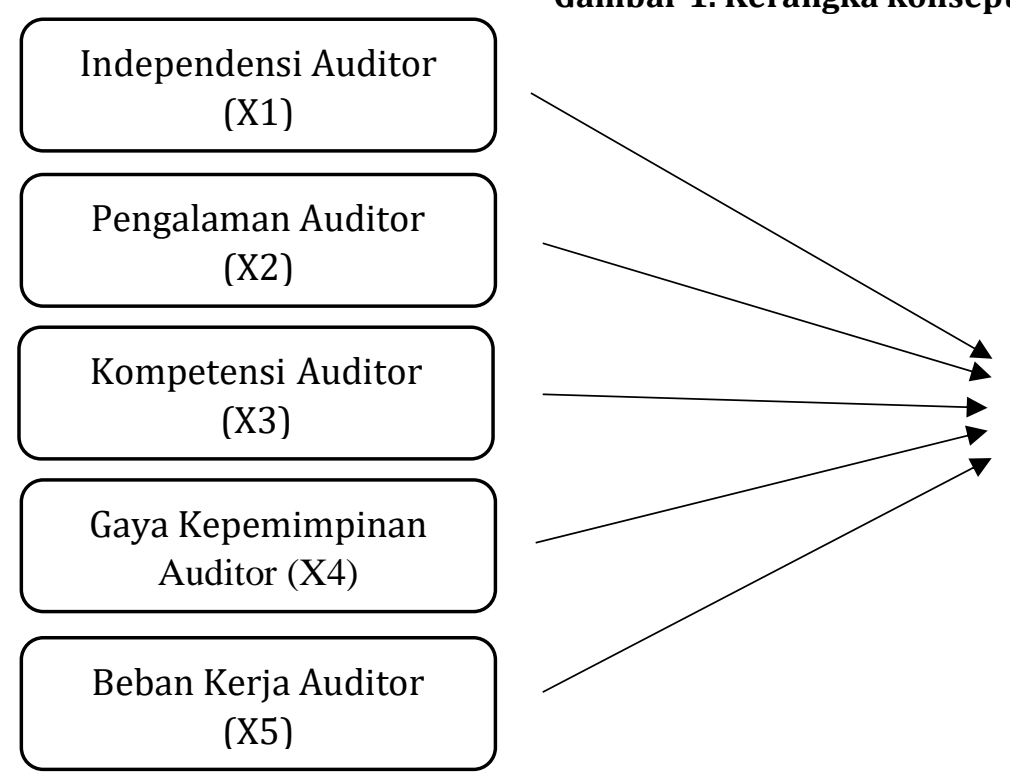

Skeptisme Profesional Auditor (Y)

Hipotesis pada penelitian ini yaitu:

H1: Independensi berpengaruh positif terhadap skeptisme professional auditor.

H2: Pengalaman berpengaruh positif terhadap skeptisme professional auditor.

H3: Kompetensi berpengaruh positif terhadap skeptisme professional auditor.

H4: Gaya kepemimpinan berpengaruh positif terhadap skeptisme professional auditor.

H5: Beban kerja berpengaruh positif terhadap skeptisme professional auditor.

\section{METODE PENELITIAN}

\section{Rancangan Penelitian}

Penelitian ini menguji pengaruh variabel $\mathrm{X}$ (Independensi auditor, pengalaman auditor, kompetensi auditor, gaya kepemimpinan auditor, dan beban kerja auditor) terhadap $\mathrm{Y}$ (skeptisme profesional auditor). Penelitian ini termasuk dalam penelitian kuantitatif dengan menggunakan desain survey deskriptif yaitu penelitian yang memaparkan secara murni hasil dari objek yang diamati. Data yang digunakan adalah data primer dan teknik data kuesioner yakni menggunakan daftar pertanyaan yang telah terstruktur dengan tujuan untuk mengumpulkan informasi.

\section{Populasi dan Sampel}

Populasi dari penelitian ini adalah auditor yang bekerja pada Kantor Akuntan Publik (KAP) di wilayah Yogyakarta. Sampel dalam penelitian ini diambil dengan menggunakan metode convenience sampling yaitu metode penentuan sample dengan pertimbangan tertentu, dimana anggota sampel yang dipilih dapat mewakili sifat-sifat populasi. Kriteria yang digunakan antara lain: auditor yang sudah pengalaman bekerja di KAP minimal satu tahun, pernah melaksanakan tugas audit minimal 2 kali, berdasarkan pada kesediaan kantor akuntan publik menerima permohonan pengisian kuesioner untuk penelitian ini. 


\section{HASIL DAN PEMBAHASAN}

Penelitian dengan menyebar kuesioner ke delapan KAP yang berada di Yogyakarta dengan rincian sebagai berikut:

Tabel 1.

Daftar Penyebaran dan Pengembalian Kuesioner

\begin{tabular}{|c|c|c|c|}
\hline No & Nama Kantor Akuntan Publik & $\begin{array}{c}\text { Kuesioner } \\
\text { Disebar }\end{array}$ & $\begin{array}{c}\text { Kuesioner } \\
\text { Kembali }\end{array}$ \\
\hline 1 & HLB Hadori Sugiarto Adi & 5 & 4 \\
\hline 2 & Drs Hardiono & 8 & 8 \\
\hline 3 & Marsun Nurdiono Kukuh Nugrahanto & 5 & 5 \\
\hline 4 & Abdul Muntalib dan Yunus & 5 & 5 \\
\hline 5 & Indarto Waluyo & 5 & 5 \\
\hline 6 & Agus Wahjono & 4 & 4 \\
\hline 7 & Kuncoro \& Rekan & 5 & 5 \\
\hline \multirow[t]{2}{*}{8} & Drs Soeroso & 3 & 3 \\
\hline & Total & 40 & 39 \\
\hline
\end{tabular}

Sumber: Data diolah, 2020

Uji validitas (uji kesahihan) adalah suatu alat yang digunakan untukmengukur sah/valid tidaknya kuesioner. Uji validitas dilakukan dengan cara menguji kolerasi antara skor item dengan skor total masing-masing variabel, menggunakan pearson correlation. Syarat yang harus dipenuhi suatu item pertanyaan untuk digunakan dalam penelitian ini adalah nilai person correlation bernilai di atas 0,3160 dan nilai signifikan lebih kecil dari 0,05.

Tabel 2.

Tabel Hasil Uji Validitas

\begin{tabular}{ccccc}
\hline Variabel & Butir Soal & $\begin{array}{c}\text { Pearson } \\
\text { Corelation }\end{array}$ & $\begin{array}{c}\text { Sig (2- } \\
\text { Tailed) }\end{array}$ & Keterangan \\
\hline Independensi & I1 & 0,628 & 0,000 & Valid \\
(X) & I2 & 0,852 & 0,000 & Valid \\
& I3 & 0,766 & 0,000 & Valid \\
& I4 & 0,839 & 0,000 & Valid \\
& I5 & 0,421 & 0,008 & Valid \\
& I6 & 0,820 & 0,000 & Valid \\
& I7 & 0,824 & 0,000 & Valid \\
& I8 & 0,798 & 0,000 & Valid \\
Pengalaman & I9 & 0,652 & 0,000 & Valid \\
(X) & P1 & 0,886 & 0,000 & Valid \\
& P2 & 0,921 & 0,000 & Valid \\
& P3 & 0,812 & 0,000 & Valid \\
& P4 & 0,756 & 0,000 & Valid \\
& P5 & 0,748 & 0,000 & Valid \\
& P6 & 0,889 & 0,000 & Valid \\
& P7 & 0,843 & 0,000 & Valid \\
& P8 & 0,756 & 0,000 & Valid \\
\hline
\end{tabular}




\begin{tabular}{|c|c|c|c|c|}
\hline Kompetensi & K1 & 0,660 & 0,000 & Valid \\
\hline \multirow[t]{9}{*}{$\left(\mathrm{X}_{3}\right)$} & K2 & 0,709 & 0,000 & Valid \\
\hline & K3 & 0,734 & 0,000 & Valid \\
\hline & K4 & 0,763 & 0,000 & Valid \\
\hline & K5 & 0,324 & 0,006 & Valid \\
\hline & K6 & 0,688 & 0,000 & Valid \\
\hline & K7 & 0,775 & 0,000 & Valid \\
\hline & K8 & 0,690 & 0,000 & Valid \\
\hline & K9 & 0,658 & 0,000 & Valid \\
\hline & K10 & 0,615 & 0,000 & Valid \\
\hline Gaya & GK1 & 0,758 & 0,000 & Valid \\
\hline \multirow{8}{*}{$\begin{array}{c}\text { Kepemimpinan } \\
\left(\mathrm{X}_{4}\right)\end{array}$} & GK2 & 0,814 & 0,000 & Valid \\
\hline & GK3 & 0,343 & 0,033 & Valid \\
\hline & GK4 & 0,805 & 0,00 & Valid \\
\hline & GK5 & 0,769 & 0,000 & Valid \\
\hline & GK6 & 0,725 & 0,000 & Valid \\
\hline & GK7 & 0,410 & 0,010 & Valid \\
\hline & GK8 & 0,816 & 0,000 & Valid \\
\hline & GK9 & 0,816 & 0,000 & Valid \\
\hline \multirow[t]{7}{*}{ Beban Kerja $\left(\mathrm{X}_{5}\right)$} & BK1 & 0,413 & 0,009 & Valid \\
\hline & BK2 & 0,828 & 0,000 & Valid \\
\hline & BК3 & 0,369 & 0,021 & Valid \\
\hline & BK4 & 0,768 & 0,000 & Valid \\
\hline & BK5 & 0,562 & 0,000 & Valid \\
\hline & BK6 & 0,700 & 0,000 & Valid \\
\hline & BK7 & 0,524 & 0,000 & Valid \\
\hline Skeptisme & SP1 & 0,812 & 0,000 & Valid \\
\hline \multirow{7}{*}{$\begin{array}{l}\text { Prefesional } \\
\text { (Y) }\end{array}$} & SP2 & 0,906 & 0,000 & Valid \\
\hline & SP3 & 0,721 & 0,000 & Valid \\
\hline & SP4 & 0,721 & 0,000 & Valid \\
\hline & SP5 & 0,883 & 0,000 & Valid \\
\hline & SP6 & 0,489 & 0,002 & Valid \\
\hline & SP7 & 0,928 & 0,000 & Valid \\
\hline & SP8 & 0,817 & 0,000 & Valid \\
\hline
\end{tabular}

Sumber: Data diolah, 2020

Uji reliabilitas ini dilakukan untuk menguji konsistensi jawaban dari responden melalui pertanyaan yang diberikan, menggunakan metode statistic Cronbach Alpha dengan signifikansi yang digunakan lebih dari (>) 0,6. Adapun hasil dari pengujian reliabilitas adalah sebagai berikut:

Tabel 3.

Hasil Uji Reliabilitas

\begin{tabular}{lcc}
\hline \multicolumn{1}{c}{ Variabel } & Cronbach's Alpha & Keterangan \\
\hline Independensi $\left(\mathrm{X}_{1}\right)$ & 0,885 & Reliabel \\
Pengalaman $\left(\mathrm{X}_{2}\right)$ & 0,933 & Reliabel \\
Kompetensi $\left(\mathrm{X}_{3}\right)$ & 0,859 & Reliabel \\
Gaya Kepemimpinan $\left(\mathrm{X}_{4}\right)$ & 0,850 & Reliabel \\
Beban Kerja $\left(\mathrm{X}_{5}\right)$ & 0,729 & Reliabel \\
Skeptisme Profesional $(\mathrm{Y})$ & 0,907 & Reliabel \\
\hline
\end{tabular}


Sumber: Data diolah, 2020

Dalam penelitian ini, untuk mempermudah dalam menganalisis regresi linier berganda penulis menggunakan program SPSS version 25. Adapun hasil analisis regresi dari data primer yang diolah dapat dilihat dalam tabel sebagai berikut:

Tabel 4.

Hasil Analisis Regresi Linier Berganda

\begin{tabular}{lccccc}
\hline \multirow{2}{*}{ Model } & \multicolumn{2}{c}{$\begin{array}{c}\text { Unstandardized } \\
\text { Coefficients }\end{array}$} & $\begin{array}{c}\text { Standardized } \\
\text { Coefficients }\end{array}$ & $\mathrm{t}$ & Sig. \\
\cline { 2 - 4 } & $\mathrm{B}$ & Std. Error & Beta & & \\
\hline 1 (Constant) & -.664 & 2.062 & & -.322 & .749 \\
Independensi & .288 & .081 & .369 & 3.573 & .001 \\
Pengalaman & .230 & .065 & .270 & 3.521 & .001 \\
Kompetensi & .210 & .084 & .241 & 2.506 & .017 \\
Gaya Kepemimpinan & .192 & .098 & .203 & 1.964 & .058 \\
Beban Kerja & .130 & .063 & .108 & 2.073 & .046 \\
\hline
\end{tabular}

Sumber: Data diolah, 2020

Persamaan regresi yang terbentuk pada uji regresi ini adalah:

$$
Y=-0,664+0,288 X_{1}+0,230 X_{2}+0,210 X_{3}+0,192 X_{4}+0,130 X_{5}
$$

Nilai konstanta bernilai -0,664. Nilai tersebut menyatakan bahwa apabila variabel independent (independensi, pengalaman, kompetensi, beban kerja, dan gaya kepemimpinan) dianggap konstan, maka rata-rata skeptisme profesional adalah sebesar -0,664 satuan.

Koefisien regresi variabel Independensi $\left(\mathrm{X}_{1}\right)$ bernilai positif sebesar 0,288. Hal ini menyatakan bahwa nilai variabel $\mathrm{Y}$ akan mengalami kenaikan sebesar 0,288 jika nilai variabel $\mathrm{X}_{1}$ mengalami kenaikan satu satuan dan variabel lainnya bernilai tetap. Koefisien positif menunjukkan adanya hubungan yang searah, emakin tinggi independensi seorang auditor maka skeptisme profesional auditor semakin meningkat.

Koefisien regresi variabel Pengalaman $\left(\mathrm{X}_{2}\right)$ bernilai positif sebesar 0,230. Hal ini menyatakan bahwa nilai variabel $\mathrm{Y}$ akan mengalami kenaikan sebesar 0,230 jika nilai variabel $\mathrm{X}_{2}$ mengalami kenaikan satu satuan dan variabel lainnya bernilai tetap. Koefisien positif menunjukkan adanya hubungan yang searah, semakin banyak pengalaman seorang auditor maka skeptisme profesional auditor semakin meningkat.

Koefisien regresi variabel Kompetensi $\left(\mathrm{X}_{3}\right)$ bernilai positif sebesar 0,210. Hal ini menyatakan bahwa nilai variabel $Y$ akan mengalami kenaikan sebesar 0,210 jika nilai variabel $\mathrm{X}_{3}$ mengalami kenaikan satu satuan dan variabel lainnya bernilai tetap. Koefisien positif 
menunjukkan adanya hubungan yang searah, semakin tinggi kompetensi seorang auditor maka skeptisme profesional auditor semakin meningkat.

Koefisien regresi variabel Gaya Kepemimpinan $\left(X_{4}\right)$ bernilai positif sebesar 0,192. Hal ini menyatakan bahwa nilai variabel Y akan mengalami kenaikan sebesar 0,192 jika nilai variabel $\mathrm{X}_{4}$ mengalami kenaikan satu satuan dan variabel lainnya bernilai tetap. Koefisien positif menunjukkan adanya hubungan yang searah, semakin baik gaya kepemimpinan seorang auditor maka skeptisme profesional auditor cenderung baik.

Koefisien regresi variabel Beban Kerja $\left(\mathrm{X}_{5}\right)$ bernilai positif sebesar 0,130. Hal ini menyatakan bahwa nilai variabel $Y$ akan mengalami peningkatan sebesar 0,130 jika nilai variabel $\mathrm{X}_{5}$ mengalami kenaikan satu satuan dan variabel lainnya bernilai tetap. Koefisien positif menunjukkan adanya hubungan yang searah, semakin tinggi beban kerja seorang auditor maka skeptisme profesional auditor semakin meningkat.

Uji F berikut ini dilakukan dengan tujuan untuk menunjukkan apakah seluruh variabel independent yang dilakukan dalam model regresi mempunyai pengaruh yang signifikan secara bersama-sama terhadap variabel dependen, maka digunakan uji F. Berdasarkan pengujian diperoleh hasil sebagai berikut:

Tabel 5.

Hasil Uji Statistik F

\begin{tabular}{llccccc}
\hline & Model & Sum of Squares & df & Mean Square & F & Sig. \\
\hline 1 & Regression & 248.390 & 5 & 49.678 & 64.662 & $.000^{\mathrm{b}}$ \\
& Residual & 25.353 & 33 & .768 & & \\
& Total & 273.744 & 38 & & & \\
\hline
\end{tabular}

Sumber: Data diolah, 2020

Hasil pengujian analisis regresi linier berganda menunjukkan bahwa nilai signifikansi sebesar 0,000. Nilai signifikansi sebesar 0,000 lebih kecil (<) daripada 0,05, maka hal ini menunjukkan bahwa hipotesis diterima yang berarti model regresi fit.

Uji koefisien determinasi bertujuan untuk mengetahui seberapa besar kemampuan variabel dependen dapat dijelaskan oleh variabel independen. Hasil dari uji determinasi tersebut sebagai berikut:

Tabel 6.

Hasil Uji Koefiien Determinasi

\begin{tabular}{ccccc}
\hline Model & $\mathrm{R}$ & R Square & $\begin{array}{c}\text { Adjusted R Square } \\
\text { Estimate }\end{array}$ & $\begin{array}{c}\text { Std. Error of the } \\
\text { Este }\end{array}$ \\
\hline 1 & $.953^{\mathrm{a}}$ & .907 & .893 & .877
\end{tabular}

Sumber: Data diolah, 2020 
Berdasarkan analisis regresi linier berganda menunjukkan besarnya koefisien determinasi (adjusted $\mathrm{r}$ square) sebesar 0,893 atau 89,3\% ini menunjukkan bahwa variabel bebas secara bersama-sama dapat menjelaskan variabel tidak bebas sebesar 89,3\% sisanya sebesar $10,7 \%$ dapat dijelaskan dengan variabel lain yang tidak terdapat dalam penelitian ini.

Uji t berikut ini menguji apakah hipotesis penelitian dapat diterima atau tidak. Jika nilai signifikansi lebih besar dari 0,05, maka hipotesis ditolah, namun jika nilai signifikansi lebih kecil dari 0,05, maka hipotesis diterima. Hasil dari uji t dapat dilihat sebagai berikut:

Tabel 7.

Hasil Uji Statistik T

\begin{tabular}{lccccc}
\hline \multirow{2}{*}{ Model } & \multicolumn{2}{c}{$\begin{array}{c}\text { Unstandardized } \\
\text { Coefficients }\end{array}$} & $\begin{array}{c}\text { Standardized } \\
\text { Coefficients }\end{array}$ & $\mathrm{t}$ & Sig. \\
\cline { 2 - 5 } & $\mathrm{B}$ & Std. Error & Beta & & \\
\hline 1 (Constant) & -.664 & 2.062 & & -.322 & .749 \\
Independensi & .288 & .081 & .369 & 3.573 & .001 \\
Pengalaman & .230 & .065 & .270 & 3.521 & .001 \\
Kompetensi & .210 & .084 & .241 & 2.506 & .017 \\
Gaya Kepemimpinan & .192 & .098 & .203 & 1.964 & .058 \\
Beban Kerja & .130 & .063 & .108 & 2.073 & .046 \\
\hline
\end{tabular}

Sumber: Data diolah, 2020

Hasil pengujian analisis regresi berganda menunjukkan bahwa terdapat nilai signifikansi sebesar $0,001 \quad(0,001<0,05)$ dengan nilai beta sebesar 0,288 . Nilai tersebut menunjukkan bahwa hipotesis pertama $\left(\mathrm{H}_{1}\right)$ diterima, yang berarti bahwa independensi seorang auditor berpengaruh terhadap tingkat skeptisme profesional auditor.

Semakin independen seorang auditor, maka sikap skeptisme profesional akan semakin meningkat. Independensi dapat diartikan sikap mental yang bebas dari pengaruh, tidak dikendalikan oleh pihak lain, tidak tergantung pada orang lain. Independensi juga berarti adanya kejujuran dalam diri auditor dalam mempertimbangkan fakta dan adanya pertimbangan yang objektif tidak memihak dalam diri auditor dalam merumuskan dan menyatakan pendapatnya. Oleh karena itu akan memperkuat sikap kritis dan teliti terhadap bukti-bukti yang dikumpulkan untuk menilai kewajaran laporan keuangan yang disebut dengan sikap skeptisme profesional auditor.

Penelitian ini sejalan dengan penelitian yang dilakukan oleh (Pratami \& Budiartha, 2019) yang mengatakan bahwa independensi auditor berpengaruh positif terhadap skeptisme profesional auditor. Karakter independensi yang tinggi akan meningkatkan skeptisme profesional auditor dan mendorong mereka untuk mencari tau lebih dalam terkait hal-hal yang dirasa mereka masih janggal. 
Hasil pengujian analisis regresi berganda menunjukkan bahwa terdapat nilai signifikansi sebesar $0,001(0,001<0,05)$ dengan nilai beta sebesar 0,230 . Nilai tersebut menunjukkan bahwa hipotesis kedua $\left(\mathrm{H}_{2}\right)$ diterima, yang berarti bahwa pengalaman seorang auditor berpengaruh terhadap tingkat skeptisme profesional auditor.

Pengalaman auditor merupakan kemampuan yang dimiliki auditor untuk belajar dari kejadian-kejadian masa lalu yang berkaitan dengan seluk-beluk audit atau pemeriksaan serta melakukan evaluasi secara kritis terhadap bukti-bukti yang ada. Semakin berpengalaman seorang auditor, maka skeptisme profesional akan semakin meningkat. Hubungan antara pengalaman dengan skeptisme profesional bersifat positif, hal ini dapat disebabkan karena semakin berpengalaman seorang auditor maka semakin besar kemampuan auditor tersebut dalam mengatasi setiap permasalahan yang ada dan bisa membantu auditor dalam memprediksi dan mendeteksi masalah secara profesional, sehingga dari situ dapat membangun sikap skeptisme auditor dan berdampak pada kualitas audit yang dihasilkan menjadi lebih baik.

Penelitian ini sejalan dengan penelitian yang dilakukan oleh (Dharmadiaksa \& Utama, 2017) yang mengatakan bahwa pengalaman kerja auditor berpengaruh positif terhadap skeptisme profesional auditor. Penelitian tersebut menyebutkan bahwa auditor yang berpengalaman memiliki tingkat selektifitas yang lebih tinggi terhadap informasi yang relevan, sehingga mempengaruhi seorang auditor untuk memiliki sikap skeptisisme profesional auditor.

Hasil pengujian analisis regresi berganda menunjukkan bahwa terdapat nilai signifikansi sebesar $0,017(0,001<0,05)$ dengan nilai beta sebesar 0,210 . Nilai tersebut menunjukkan bahwa hipotesis ketiga $\left(\mathrm{H}_{3}\right)$ diterima, yang berarti bahwa kompetensi seorang auditor berpengaruh terhadap tingkat skeptisme profesional auditor.

Kompetensi auditor merupakan kemampuan profesional individu auditor dalam menerapkan pengetahuan untuk menyelesaikan suatu perikatan baik secara-sama dalam suatu tim atau secara mandiri berdasarkan Standar Profesional Akuntansi Publik. Semakin berkompeten seorang auditor, maka sikap skeptisme profesional akan semakin meningkat. Hal ini disebabkan karena seorang auditor yang berkompeten dapat menerapkan sikap skeptisme profesional auditor yang diperolehnya dari pelatihan-pelatihan maupun dari ilmu yang didapat dari perguruan tinggi atau sekolah profesi, dalam melakukan tugas-tugas audit yang diterimanya.

Penelitian ini sejalan dengan penelitian yang dilakukan oleh (Komala et al., 2019) yang mengatakan bahwa kompetensi auditor berpengaruh positif terhadap skeptisme profesional auditor. Hal ini berarti semakin meningkat kompetensi yang dimiliki oleh seorang auditor maka semakin tinggi juga sikap skeptisisme profesional auditor.

Hasil pengujian analisis regresi berganda menunjukkan bahwa terdapat nilai signifikansi sebesar 0,058 mendekati nilai 0,05 dan tidak lebih besar darpada 0,10, dengan nilai beta sebesar 0,192. Nilai tersebut menunjukkan bahwa hipotesis keempat $\left(\mathrm{H}_{4}\right)$ diterima, yang 
berarti bahwa gaya kepemimpinan seorang auditor berpengaruh terhadap tingkat skeptisme profesional auditor.

Gaya kepemimpinan (leadership style) diartikan sebagai hal yang dilakukan pemimpin untuk memberikan pengaruh pada bawahannya sehingga orang yang diberikan pengaruh tersebut mau melakukan perintah pemimpin demi mencapai tujuan organisasi. Semakin baik pimpinan Kantor Akuntan Publik memimpin maka sikap skeptisme profesional bawahan juga akan meningkat. Hubungan antara gaya kepemimpinan dan skeptisme profesional auditor bersifat positif, hal ini disebabkan karena kepemimpinan yang baik dan diterima semua anggota organisasi cenderung dapat mendorong auditor untuk melakukan kewajibannya sesuai dengan standar yang berlaku, mengutamakan kualitas dengan meningkatkan skeptisme dalam mendeteksi kecurangan yang terjadi.

Penelitian ini sejalan dengan penelitian yang dilakukan oleh (Pratami \& Budiartha, 2019) yang mengatakan bahwa gaya kepemimpinan berpengaruh secara positif pada skeptisme profesional auditor. Semakin baik pimpinan Kantor Akuntan Publik memimpin maka sikap skeptisme profesional bawahan juga akan meningkat.

Hasil pengujian analisis regresi berganda menunjukkan bahwa terdapat nilai signifikansi sebesar $0,046(0,046<0,05)$ dengan nilai beta sebesar 0,130 . Nilai tersebut menunjukkan bahwa hipotesis kelima $\left(\mathrm{H}_{5}\right)$ diterima, yang berarti bahwa beban kerja seorang auditor berpengaruh terhadap tingkat skeptisme profesional auditor.

Tingginya beban kerja (workload) seorang auditor, yang mana auditor memiliki banyak tugas yang harus diselesaikan sedangkan waktu yang dimiliki terbatas sehingga variasi dalam pencarian informasipun akan beragam. Auditor jadi lebih banyak menyakan dan mencari-cari bukti audit yang dirasa janggal untuk ditanyakan lebih dalam. Hal ini menunjukkan bahwa beban kerja berpengaruh terhadap skeptisme professional auditor, semakin berat beban kerja seorang auditor maka sikap skeptisme professional auditor juga semakin meningkat.

Penelitian ini sejalan dengan penelitian yang dilakukan oleh (Novita, 2015) yang mengatakan bahwa beban kerja auditor berpengaruh terhadap skeptisme profesional auditor. Semakin besar beban auditor yang dilakukan oleh auditor maka sikap skeptisme auditor akan semakin meningkat.

\section{KESIMPULAN}

Berdasarkan hasil analisis dan pembahasan yang dibahas sebelumnya dapat ditarik kesimpulan bahwa independensi berpengaruh terhadap skeptisme professional auditor. Pengalaman berpengaruh terhadap skeptisme professional auditor. Kompetensi berpengaruh terhadap skeptisme professional auditor. Gaya kepemimpinan berpengaruh terhadap skeptisme professional auditor. Beban kerja berpengaruh terhadap skeptisme professional auditor. 
Keterbatasan pada penelitian ini adalah Penelitian ini dilaksanakan pada rentang waktu Desember 2019 sampai dengan Januari 2020, dimana pada periode akhir tahun ini merupakan waktu tersibuk seorang auditor yang mengharuskan mereka untuk mengaudit sebuah laporan keuangan klien mereka, sehingga dalam pengumpulan data penelitian auditor yang menjadi responden dinilai kurang objektif dalam memberikan jawaban atas kuesioner penelitian.

Berdasarkan keterbatasan tersebut peneliti memberi saran yaitu peneliti yang akan datang tidak disarankan untuk melaksanakan penelitian di akhir tahun atau awal tahun karena itu merupakan waktu tersibuk auditor yang mengharuskan mereka mengaudit laporan keuangan klien, sehingga dalam pengumpulan data penelitian auditor yang menjadi responden dinilai kurang objektif dalam memberikan jawaban atas kuesioner penelitian. Kepada peneliti yang akan datang, disarankan juga untuk mendapatkan data selain menyebarkan kuesioner juga melakukan wawancara dari auditor yang menjadi responden penelitian, agar bias penggunaan angket kuesioner dapat dihindari yang mungkin terlalu sempit atau kurang menggambarkan keadaan yang sesungguhnya.

\section{DAFTAR PUSTAKA}

Dewi, D., \& Budiartha, I. (2015). Pengaruh Kompetensi Dan Independensi Auditor Pada Kualitas Audit Dimoderasi Oleh Tekanan Klien. E-Jurnal Akuntansi, 11(1), 197-210.

Dharmadiaksa; I. B., \& Utama; I. M. K. (2017). Pengaruh Indepedensi Dan Pengalaman Auditor Pada Skeptisisme Profesional Auditor Serta Implikasinya Pada Kualitas Audit. Jurnal Riset Akuntansi, 7(1), 1-12.

Hadi, S. (2014). Pengaruh Independence In Attitude Dan Pengalaman Terhadap Skeptisisme Profesional Auditor. VIII(2), 218-234.

Ilmiyati, F., \& Suhardjo, Y. (2012). Pengaruh Akuntabilitas Dan Kompetensi Auditor Terhadap Kualitas Audit. Juraksi, 1(1), 43-56.

Komala, A. R. \& Suryani, E. (2019). Pengaruh Independensi, Kompetensi, dan Pengalaman Auditor Terhadap Skeptisme Profesional Auditor. e-Proceeding of Management. Vol.6: 2 (32253232).

Pratami, I. A. P. D. W. \& Budiarta, I. K.. (2019). Pengaruh Independensi dan gaya Kepemimpinan pada Skeptisme Profesional Auditor. E-Jurnal Akuntansi, 28(1), 722-747.

Ranu, G. A. Y. N. (2017). Kemampuan Mendeteksi Fraud Berdasarkan Skeptisme Profesional, Beban Kerja, Pengalaman Audit dan Tipe Kepribadian Auditor. Jurnal Riset Akuntansi Juara, 7(1), 79-90.

Suraida, I. (2005). Pengaruh Etika, Kompetensi, Pengalaman Audit dan Risiko Audit terhadap Skeptisisme Profesional Auditor dan Ketepatan Pemberian Opini Akuntan Publik. Sosiohumaniora, 7(3), 186-202.

Seputra, Yulius Eka Agung. (2013). Audit Berbantuan Kontemporer. Yogyakarta: Gava Media.

Sofyan, A., -, A., \& Novita, U. (2015). Pengaruh Pengalaman, Beban Kerja, Dan Pelatihan Terhadap Skeptisme Dan Kemampuan Auditor Dalam Mendeteksi Kecurangan. Jurnal Online Mahasiswa Fakultas Ekonomi Universitas Riau, 2(1), 1-16.

Wijaya, P. S. (2015). Pengaruh Komitmen Organisasi, Budaya Organisasi, Gaya Kepemimpinan Dan Lingkungan Terhadap Kinerja Karyawan Pada Industri Kecil. Jurnal Ekonomi 
Pengaruh Independensi, Pengalaman, Kompetensi, Gaya Kepemimpinan, Dan Beban Kerja Auditor

MODERNISASI, 11(1), 62-77.

Winantyadi, N. \& Waluyo, I. (2014). Pengalaman, Keahlian, Situasi Audit, Etika, Skeptisisme Profesional Auditor. Jurnal nominal. 3(1), 13-34. 